\title{
Ocorrência de um Potyvirus Associado ao Mosaico da Açucena-Gigante
}

\author{
Antônio A.L. Barboza ${ }^{1}$, Eliezer R. de Souto ${ }^{1}$, Álvaro M.R. Almeida ${ }^{2}$ \& Elliot W. Kitajima ${ }^{3}$ \\ ${ }^{1}$ Departamento de Agronomia, Universidade Estadual de Maringá, Av. Colombo, 5790, CEP 87020-900,

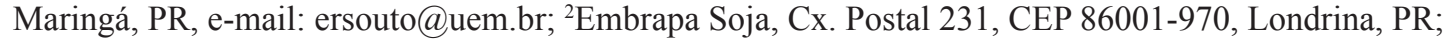 \\ ${ }^{3}$ Setor de Fitopatologia, NAP/MEPA, ESALQ, Cx. Postal 9, CEP 13418-900, Piracicaba, SP
}

(Aceito para publicação em 20/01/2006)

Autor para correspondência: Eliezer Rodrigues de Souto

\begin{abstract}
Association of a Potyvirus with mosaic symptoms in spider lily

Plants of spider lily (Crinum $s p$ ) showing mosaic symptoms were found in Londrina, Paraná. Electron microscopy examinations revealed flexuous rod shaped particles and lamellar inclusion bodies in the cell cytoplasm. RT-PCR products of $2 \mathrm{~kb}$ were amplified by a pair of genus specific primers suggesting the association of a potyvirus, being this the first time a virus infection in this host is reported in Brazil.
\end{abstract}

Potyvirus como o Lily symptomless virus (LSV), Lily mottle virus (LMoV) e Tulip breaking virus (TBV), podem causar sintomas de mosaico, anormalidades de crescimento e redução no tamanho de flores em plantas de caule subterrâneo bulboso como o lírio, família Liliaceae (Hagita et al., Annals Phytopathological Society Japan 55:1. 1989). Na Austrália, há o relato de um potyvírus restrito a Crinum $s p$, família Amaryllidaceae, o qual ainda não foi caracterizado, causando clorose generalizada, mosaico e manchas estriadas nas folhas (Pares \& Bertus, Phytopathologische Z. 91:170. 1978). Bulbos originários de açucena-gigante (Crinum sp) com sintomas de mosaico, coletados em Londrina, produziram plantas que manifestaram mosaico leve progredindo para manchas avermelhadas e necrose das folhas mais velhas. As inoculações mecânicas de macerados foliares em plantas de sete famílias botânicas, incluindo Liliaceae e Amaryllidaceae, foram negativas. Todavia, ensaios de RTPCR com oligonucleotídeos específicos para a terminação 3' do genoma de potyvirus (Chavi et al., Plant Disease 81:1115. 1997; Colinet et al., Plant Disease 82: 223. 1998), resultaram em amplificações de aproximadamente $2 \mathrm{~kb}$. Exames de microscopia eletrônica revelaram partículas alongadas e agregados lamelares no citoplasma das células infectadas. $\mathrm{O}$ sequenciamento do produto de RT-PCR obtido poderá elucidar em definitivo a identidade e a posição taxonômica do vírus associado à açucena-gigante no Paraná.

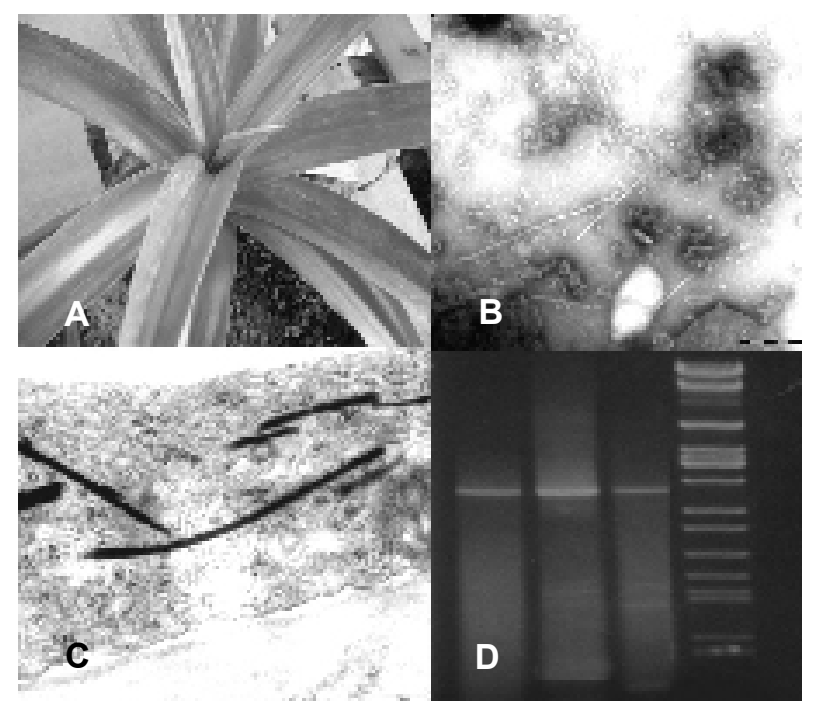

FIG.1- A. Mosaico em açucena-gigante; B. Partículas alongadas e flexíveis em preparação "leaf dip"; C. Agregados lamelares no citoplasma; D. Produtos de amplificação de RT-PCR ( 2 kb). Marcador DNA $\lambda$ digerido com as enzimas Eco RI, Hind III e Bam HI. 